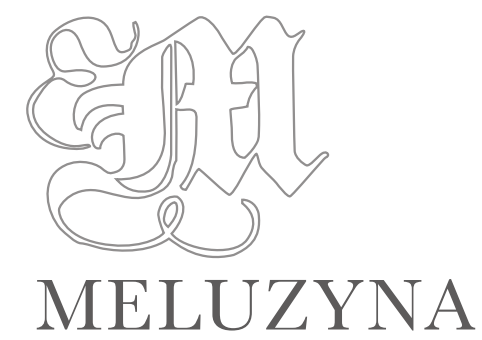

ISSN 2449-7339

2 (5) (2016) I Rocznik III

DOI: 10.18276/me.2016.2-05

KONTEKSTY I NAWIAZZANIA

\title{
Agnieszka Saganiak*
}

Uniwersytet Wrocławski

\section{Nazwy własne (antroponimy) w polskich przekładach powiastki filozoficznej Voltaire'a Candide ou l'optimisme ${ }^{1}$}

\section{Wstęp}

Candide ou l'optimisme to bez wątpienia najbardziej znana powiastka filozoficzna w dorobku Voltaire’a. Utwór został opublikowany w Genewie w 1759 roku, a jego pierwsze polskie tłumaczenie zatytułowane Kandyd Wszędobylski czyli najlepszość wyszło spod pióra Jacka Idziego Przybylskiego i ujrzało światło dzienne w 1780 roku, dwadzieścia jeden lat po publikacji oryginału (Voltaire, 1780). Drugi i do tej pory ostatni przekład powiastki pojawił się dopiero w 1917 roku². Jego twórca - wybitny polski tłumacz Tadeusz Boy-Żeleński - postawił na krótszą i bliższą oryginałowi formę tytułu: Kandyd czyli optymizm³.

Celem niniejszego artykułu jest zbadanie wpływu horyzontu translatorskiego na wybór strategii tłumaczeniowych polskich tłumaczy powiastki Voltaire’a w zakresie przekładu nazw własnych. Pojęcie horyzontu translatorskiego zostało wprowadzone do przekładoznawstwa przez Antoine’a Bermana i oznacza zespół czynników językowych, literackich, kulturowych i historycznych wpływających na podmiot tłumaczący ${ }^{4}$. Biorąc pod uwagę, że tłumaczenia, którymi

\footnotetext{
e-mail autorki: agnieszka.saganiak@gmail.com

1 Artykuł został przygotowany na podstawie pracy licencjackiej z 2016 roku zatytułowanej Le traitement des anthroponymes dans les traductions polonaises de "Candide" de Voltaire.

2 Voltaire, Kandyd, 1917. Przykłady wykorzystane w niniejszej pracy pochodzą z wydania z 1931 roku - ostatniego przed śmiercią tłumacza (Voltaire, 1931).

3 Tłumaczenia powiastki podejmowali się również: Józef Mikołaj Wiślicki, Stanisław Kostka Potocki (jedynie pierwsze rozdziały) oraz Grzegorz Glass (fragmenty) (Wójcicki, 2006, s. 232; Brudnicka, 1964, s. 481; Voltaire, 1911, s. 55-57, 162-164).

4 Berman, 1995. Cyt. za: Chrobak, 2009, s. 9-11.
} 
będziemy się zajmować, są oddalone od siebie w czasie aż o sto pięćdziesiąt lat, refleksja nad decyzjami tłumaczy w kwestii nazw własnych może przynieść interesujące rezultaty na temat szerszego zjawiska serii przekładowej, której przykładem są oba tłumaczenia. O powstaniu tej serii zadecydował zapewne czynnik historyczny ${ }^{5}$ - z powodu „zestarzenia się” pierwszego tłumaczenia należało wykonać kolejne. Wydaje się zatem, że bezpośrednią przyczyną jego powstania jest zmiana horyzontu translatorskiego w czasie.

Jako przedmiot badań zostały wybrane nazwy własne, gdyż stanowią one ogromne wyzwanie dla każdego tłumacza z racji swojej problematyczności, podkreślanej przez wielu lingwistów i translatologów. Już samo stworzenie dokładnej i jednoznacznej definicji nazwy własnej jest zadaniem niezwykle trudnym. Choć istnieją tradycyjne kryteria mające pomóc w odróżnieniu nazwy własnej od nazwy pospolitej, nie w każdym przypadku są one możliwe do zaakceptowania ${ }^{6}$. Problematyczność ta wynika również z wielości możliwych interpretacji nazwy własnej. Jej zrozumienie zależy często wyłącznie od informacji dostarczanych przez kontekst, w którym się pojawia. Interpretacja może się także zmieniać w zależności od funkcji składniowej, którą przybiera dana nazwa wewnątrz grupy nominalnej (Gary-Prieur, 1991, s. 19-21). Interesujące jest zatem zbadanie tego, jak obaj tłumacze poradzili sobie z tak niejednoznaczną kategorią, zwłaszcza że nazwa własna stanowi nie tylko część języka, ale także, a może przede wszystkim, jest odzwierciedleniem kultury. Rola tłumacza jako pośrednika międzykulturowego staje się tutaj szczególnie ważna (Ballard, 2001, s. 108).

Za nazwę własną w utworze Voltaire’a uznajemy każdą nazwę, która posiada swój unikatowy desygnat w świecie omawianej powiastki. Bierzemy pod uwagę nazwy złożone, w których mogą występować nazwy apelatywne, niezależnie od tego, czy odpowiadają one tradycyjnym kryteriom definicji nazwy własnej. Ze względu na liczną obecność nazw własnych w tekście oryginału zawężamy przedmiot badań jedynie do antroponimów. Te zaś są bardzo liczne i różnorodne - znajdujemy tu zarówno neologizmy, jak i imiona autentyczne, a ich desygnaty to nie tylko bohaterowie wykreowani na potrzeby utworu, ale także postaci historyczne, literackie, związane z religią albo z życiem samego autora. Ponadto nazwy własne pełnią konkretne funkcje w tekście; w szczególności widoczna jest funkcja semantyczna ${ }^{7}$, której obecność całkowicie zaprzecza tradycyjnemu poglądowi, że nazwa własna nie posiada sensu, a jedynie referencję jednostkową (Leroy, 2004, s. 19-24).

\section{Tłumacze i ich horyzont translatorski}

Jacek Idzi Przybylski (1756-1819) - wykładowca języków starożytnych na Akademii Krakowskiej oraz tłumacz poezji greckiej, łacińskiej i współczesnej - był znany głównie z przekładów wielkich dzieł literatury antycznej. Posługiwał się biegle łaciną, której nauczył się w Kolegium Nowodwor-

5 O serii przekładowej i czynnikach, które wpływają na jej powstanie zob. Skibińska, 2011, s. 405-418.

6 Sarah Leroy podaje tradycyjne kryteria definicji nazwy własnej: formalne (wielka litera, nieprzekładalność i brak nazwy własnej w słownikach), morfosyntaktyczne (brak determinantu i brak fleksji) oraz semantyczne i pragmatyczne (brak znaczenia, referencja jednostkowa). Jednocześnie ukazuje ich niefunkcjonalność za pomocą kontrprzykładów (Leroy, 2004, s. 7-24).

7 Nazewnictwo funkcji zapożyczamy od Czesława Kosyla (Kosyl, 1992). 
skim w Krakowie, oraz greką, a także francuskim, angielskim i włoskim, których nauczył się samodzielnie. Podziwiał Voltaire’a i przetłumaczył przynajmniej pięć jego powiastek, choć nie wszystkie przekłady ujrzały światło dzienne ${ }^{8}$. Szczególne zainteresowanie tłumacza dziełami tego francuskiego filozofa obserwujemy w okresie od 1780 (poczynając od przekładu Kandyda) do 1784 r. Oprócz powiastek, wydawanych często bezimiennie, Przybylski przetłumaczył również poświęcone Voltaire’owi dzieło encyklopedyczne z języka niemieckiego (Zabuesnig, 1781; także Zabuesnig, 1784). Tłumacz po śmierci był krytykowany i szybko został zapomniany. Zarzucano mu między innymi tendencję do używania w tłumaczeniach zbyt wielu amplifikacji i neologizmów.

Przybylski żył w czasach, które są niezwykle ważne dla historii polskiego przekładu. To właśnie w XVIII wieku toczyły się liczne dyskusje na temat sztuki tłumaczenia, pojawiały się także pierwsze dzieła krytyczne. Wybór strategii tłumaczeniowej zależał między innymi od gatunku literackiego. Tłumacze dążyli do ulepszania stylu oryginału poprzez stosowanie licznych amplifikacji, co potwierdzają na przykład niezwykle rozbudowane tytuły przekładów (Ziętarska, 1969, s. 80). Najczęściej tłumaczono z języka francuskiego, który był najważniejszy w oświeceniowej Europie. Elity Francji i Polski wciąż jednak posługiwały się biegle łaciną, znały grekę.

W polskiej literaturze dominowała funkcja dydaktyczna, natomiast powiastka była uznawana za genre mineur, o czym świadczy niewielka liczba tłumaczeń z tego gatunku oraz brak tekstów krytycznych, wstępów czy komentarzy tłumacza. Przekłady publikowano często bez ujawniania nazwiska autora i tłumacza, z fikcyjnym adresem wydawniczym. Sam Voltaire był postrzegany jako wróg Kościoła, krytykujący w swoich utworach religię chrześcijańską i ówczesną rzeczywistość społeczno-polityczną (Sinko, 1982, s. 15, 125, 159). Przekłady utworów Voltaire’a nie były zatem doceniane przez współczesnych Przybylskiemu, a sam tłumacz prawie nigdy nie mówił o swojej pracy (Snopek, 1994, s. 207-229; Wójcicki, 2006, s. 7-23; Chrobak, 2009, s. 8).

Tadeusz Boy-Żeleński (1874-1941) był przede wszystkim tłumaczem, ale także pisarzem, krytykiem literackim i teatralnym oraz lekarzem. Przetłumaczył na język polski największe dzieła literatury francuskiej, autorstwa między innymi Molière’a, Balzaca, Descartes’a czy Voltaire’a. W czasie pierwszej wojny światowej założył serię wydawniczą „Biblioteka Boya”, która stała się symbolem jego twórczości przekładowej. Tłumacz wypracował własny niepowtarzalny styl i warsztat. Jego fascynacja Francją zrodzona w czasie pobytów w Paryżu zaowocowała ponad setką tłumaczeń z tego języka. Ich powstanie wyjaśnić można, przytaczając słowa samego Boya z napisanego w 1921 roku wstępu do Antologii literatury francuskiej:

Żyliśmy jeden wiek w niewoli; dwa poprzednie bez mała w głębokiej ciemnocie. Zatamowano nam tyle źródeł myśli, okaleczono tyle dziedzin ducha, brak nam mnóstwa, mnóstwa rzeczy bardziej jeszcze w sferze intelektualnej niż jakiejkolwiek innej. Żadna literatura współczesna nie da prawdziwej kultury umysłu: zanadto jest odbiciem chwili, za wiele ma elementów mijania, za mało jest gęsta. Na pożywny bulion myśli trzeba wieków. Zwróćmy się tedy do Francji po to, czego nam nie staje: jest to, jak nasza naturalna sojuszniczka w polityce, tak i nasza wypróbowana nauczycielka w myśleniu. Mamy własnych wspaniałych romantyków; uczyńmy sobie z pisarzy francuskich swoich klasyków (Żeleński-Boy, 1958, s. 43-44).

\footnotetext{
8 Przekłady Dobrego Bramina oraz Memnona zostały opublikowane bezimiennie (Voltaire, 1781a; Voltaire 1781b).
} 
Za czasów Boya zmieniały się również normy języka polskiego, o czym świadczy przeprowadzona w 1936 roku duża reforma ortografii ujednolicająca zasady obowiązujące na terytorium całego kraju (zob. też Strycharska-Brzezina, 2012). Boy był zwolennikiem zmian również w kwestiach związanych ze stylem pisarskim ówczesnych twórców. W wypowiedziach krytyczno-literackich wielokrotnie manifestował dezaprobatę w stosunku do sposobu pisania właściwego Młodej Polsce. Postulował powrót do prostoty formy oraz odrzucenie manieryzmu i „dekorowania” tekstu, co było charakterystyczne właśnie dla tej epoki. Dążył również do wprowadzenia do literatury elementów życia codziennego, np. języka potocznego. Krytykował zarówno frazeologię, którą uważał za pustą, jak i mistycyzm, polegający na postrzeganiu artystów jako wzniosłych postaci. Sam zaś - w swej pracy translatorskiej - okazał się „niezwykłym stylistycznym transformistą, magikiem i czarodziejem prawie”, „rekordzistą przekładu, maratończykiem tłumaczenia”, który „każdy prawie zakręt w biegu po laury brał w nieposzlakowanym stylu” (Błoński, 1958, s. 7-11; zob. też Jean, 1976; Stróżyński 1994; Hen, 2008; Kozioł, 2010).

\section{Nazwy własne w przekładach}

Antroponimy występujące w powiastce zostały podzielone na dwie grupy: nazwy bohaterów oraz nazwy postaci przywoływanych przez bohaterów w dialogach lub monologach. Nazwy z pierwszej grupy zostały dodatkowo podzielone na nazwy postaci fikcyjnych i autentycznych. W drugiej grupie zaś wyodrębniliśmy trzy podgrupy: nazwy postaci autentycznych związanych z Voltaire’em, nazwy postaci historycznych oraz nazwy postaci literackich i postaci związanych z religią.

\section{Nazwy bohaterów powiastki, postaci fikcyjne}

Analizę imion bohaterów powiastki zaczniemy od neologizmów, ponieważ prawie wszystkie spośród nich pełnią funkcję semantyczną. Imiona te są znaczące i zwykle wskazują na cechy charakteru postaci, na przykład candide jest przymiotnikiem wywodzącym się z łaciny (candidus 'biały', także 'szczery', 'otwarty'), który Voltaire przekształcił w nazwę własną, aby oddać niewinność i prostotę głównego bohatera.

Nazwy zawarte w tej grupie mogą również pełnić funkcję socjologiczną, głównie przez swoją formę. Nazwa odnosząca się do barona, u którego mieszkał Kandyd w Westfalii: le baron de Thunder-ten-tronckh wskazuje na przynależność do wysokich kręgów społecznych tej postaci dzięki użyciu partykuły de. Nazwa ta pełni także funkcję ekspresywną, co ujawnia się w dużym nagromadzeniu spółgłosek, mającym przywoływać na myśl cechy charakterystyczne języka, którym posługuje się bohater i co wywołuje efekt komiczny. Taką samą funkcję pełni imię rządcy o hiszpańskim pochodzeniu, które brzmi don Fernando d'Ibaraa, y Figueora, y Mascarenes, y Lampourdos, y Souza. Poza funkcją ekspresywną nazwa ta pełni również funkcję charakteryzującą. Bohater ten nosił tak dużo imion, gdyż jego główną cechą była pycha - wskazuje na to następujący cytat:

Ce seigneur avait une fierté convenable à un homme qui portait tant de noms. Il parlait aux hommes avec le dédain le plus noble, portant le nez si haut... 
Pan ów odznaczał się dumą, jaka przystała posiadaczowi tylu imion. Przemawiał do ludzi z najszlachetniejszą wzgardą, zadzierając nos tak wysoko...

(Voltaire, 1931, s. 43).

Zobaczmy teraz, czy opisane wyżej funkcje nazw własnych zostały zachowane w polskich tłumaczeniach:

(1)

Voltaire: Candide

Przybylski, Boy: Kandyd

Przybylski (tytuł): Kandyd Wszędybylski

(2)

V: Pangloss

P: Pangloz

B: Pangloss.

Pierwsze dwa przykłady pokazują traktowanie nazw, które są znaczące i pełnią w tekście funkcję semantyczną. Imię Candide odwołuje się do prostoty głównego bohatera i zostało przeniesione oraz spolszczone przez obu tłumaczy. Imię Pangloss, które odnosi się do nauczyciela Kandyda, głoszącego wyśmianą w powiastce Leibnizowską filozofię optymizmu, pochodzi z greki i składa się z dwóch słów: pan 'wszystko' i gloss 'język'. Filozof nosi to imię dlatego, że mówi bez przerwy, nawet w niebezpiecznych sytuacjach i nawet wtedy, gdy zostaje ukarany przez Inkwizycję za to, że za dużo mówił. Nazwa została przeniesiona oraz spolszczona przez Przybylskiego, a przez Boya tylko przeniesiona, bez żadnej zmiany w pisowni.

Funkcja semantyczna obu imion jest z pewnością widoczna dla XVIII-wiecznych czytelników przekładu Przybylskiego, biorąc pod uwagę, iż ówczesne elity intelektualne posługiwały się swobodnie zarówno łaciną, jak i greką. Poza tym znaczenie imienia głównego bohatera jest wytłumaczone przez samego Voltaire’a na pierwszej stronie utworu. W tłumaczeniu Boya znaczenie drugiej nazwy nie jest już tak łatwo rozpoznawalne jak pierwszej. Nie znajdujemy w tekście oryginału żadnej wskazówki pozwalającej odgadnąć funkcję semantyczną imienia Pangloss. W XX stuleciu, zwłaszcza w 2. połowie, znajomość łaciny czy greki nie była już tak powszechna jak w XVIII wieku. Istnieje zatem mniejsze prawdopodobieństwo, że polscy czytelnicy (oczywiście poza tymi, którzy rzeczywiście posługują się greką) zorientują się, iż imię myśliciela ma konkretne znaczenie.

Interesujące jest również potraktowanie imienia głównego bohatera $\mathrm{w}$ tytule tłumaczenia Przybylskiego. Tłumacz dodał do imienia nazwisko Wszędybylski, które miało być zapewne aluzją do licznych podróży odbywanych przez Kandyda po całym świecie, nie zawsze z własnej woli. Dodanie to wynika zapewne z chęci zachowania ówczesnego zwyczaju charakteryzowania bohatera właśnie za pomocą nazwiska (np. Mikołaj Doświadczyński), a także z ogólnej tendencji Przybylskiego do stosowania licznych amplifikacji, co widać doskonale w tytułach innych jego tłumaczeń, na przykład: Énéide = Eneida, czyli wiersz bohatyrski ku czci Enejasza z Troi. Jak zauważa Marzena Chrobak w książce Optymizm Kandy- 
da oraz inne problemy oświeconych tłumaczy (Chrobak, 2009), taka amplifikacja nie oddaje stylu Voltaire’a, który jest bardzo zwięzły. Uzupełnienie to - które wydaje się niepotrzebne - można uznać za wynik upodobań samego tłumacza, ale też - za podporządkowanie normom epoki, w której tworzył Przybylski (wspomniane wyżej tendencje do stosowania amplifikacji). W kolejnych trzech przykładach -

(3)

V: le baron de Thunder-ten-tronckh

P: Baron de Thunder-ten-tronckh

B: baron de Thunder-ten-tronckh, baron Thunder-ten-tronckh

(4)

V: Don Fernando d'Ibaraa, y Figueora, y Mascarenes, y Lampourdos, y Souza

P: Dom Ferdynando d'Ibaraa y Figueora y Maskaranes y Lampurdos y Suza

B: don Fernando d'Ibaara y Figueora y Maskarenes y Lampurdos y Suza

V: la marquise de Parolignac

P: margrabina de Paroliniak

B: margrabina de Parolignac

- widzimy, że funkcje: ekspresywna, charakteryzująca i socjologiczna zostały zachowane przez obu tłumaczy. Partykuła de wskazująca na pozycję społeczną w (3) i (5) jest również obecna w obydwu polskich tłumaczeniach. W przykładach (3) i (4) nazwy własne zostały przeniesione przez tłumaczy z niewielkimi zmianami w pisowni w przypadku (4). Można jednak zauważyć znaczącą różnicę w traktowaniu nazwy z przykładu (5). Obaj tłumacze przetłumaczyli słowo la marquise jako margrabina i zachowali partykułę de. Biorąc pod uwagę, że tytuł margrabiego odnosił się do rządcy terenami przygranicznymi w dawnych Niemczech (Święte Cesarstwo Rzymskie), zastosowanie takiego rozwiązania przez autorów przekładów nie wydaje się odpowiednie, zwłaszcza że istnieje w języku polskim francuskie zapożyczenie, czyli markiza. Nie możemy jednak być pewni czy termin ten, poświadczony w pierwszej połowie XVIII wieku (Bochnakowa i in., 2012, s. 200), był w powszechnym użyciu w latach 80. Poza tym widzimy, że Przybylski spolszczył słowo Parolignac, natomiast Boy przeniósł je do tłumaczenia w niezmienionej formie. Funkcja semantyczna tej nazwy, ujawniająca się w słowie paroli (związanym między innymi z grą w karty) i wskazująca na zamiłowanie bohaterki do hazardu, może być widoczna w obu tłumaczeniach jedynie dzięki kontekstowi. We fragmencie, w którym imię markizy zostaje użyte po raz pierwszy w utworze, jest mowa właśnie o grze w karty, a także pojawia się nazwa pospolita paroli, którą tłumacze również przenieśli do tekstu tłumaczenia: Przybylski w niezmienionej formie paroli, a Boy w wersji polskiej parole. Następne nazwy to:

(6)

V: le frère Giroflée

P: xiądz Kartofel, Kartofel

B: brat Żyrofla 
(7)
V: Pococuranté
P: Pokokurant, Pokokuranty
B: Prokurant.

Dwa ostatnie przykłady traktowania neologizmów różnią się znacznie od poprzednich. Tłumacze użyli odmiennych technik w przekładzie nazw, które w oryginale pełnią funkcję semantyczną. Dosłowny przekład nazwy le frère Giroflée to 'brat Lewkonia'. Dzięki opisowi zawartemu w oryginale możemy przypuszczać, że Voltaire chciał przez to imię oddać dobre zdrowie, jakim cieszy się duchowny oraz ogólny dobrobyt, w jakim żyje:

la fleur de la santé brille sur votre visage, votre physionomie annonce le bonheur; vous avez une très jolie fille pour votre récréation, et vous paraissez très content de votre état de théatin

(Voltaire, 1889, s. 189)

zdrowie tryska z twojej twarzy, fizjognomja zwiastuje szczęście; masz oto, dla uciechy, bardzo ładną dziewczynę, i wydajesz się wcale rad ze swego teatyńskiego stanu

(Voltaire, 1931, s. 83).

W dosłownym tłumaczeniu to 'kwiat zdrowia' błyszczy na twarzy teatyna. Oczywiście imię to zostało nadane duchownemu ironicznie, gdyż Voltaire krytykuje w swojej powiastce nadużycia władzy i duchowieństwa. W przekładzie Przybylskiego wspomniany ksiądz funkcjonuje pod nazwą Kartofel. Tłumacz zastąpił nazwę oryginalną inną nazwą, ale pochodzącą również ze świata botaniki. Boy-Żeleński postanowił przenieść brzmienie nazwy francuskiej pod spolszczoną formą. Według Chrobak (Chrobak, 2009) rozwiązanie Przybylskiego bardzo dobrze oddaje cechy charakteru postaci oraz wywołuje efekt komiczny. Kartofel może, naszym zdaniem, wywoływać również konotacje pejoratywne związane z grubiaństwem czy głupotą. Odbiór takiego imienia jest subiektywny i nie można jednoznacznie ocenić, czy tłumacz zachował funkcję semantyczną. Jeśli chodzi o rozwiązanie Boya, to raczej nie oddaje ono znaczenia imienia obecnego w oryginale - Żyrofla może nic nie znaczyć dla polskiego czytelnika, gdyż termin ten nie figuruje w Słowniku języka polskiego z 1927 roku (Karłowicz, Kryński, Niedźwiedzki, 1927).

Ostatni przykład z tej serii przedstawia traktowanie imienia Pococuranté, które nosił spotkany przez Kandyda senator. Nazwa ta składa się z dwóch słów pochodzenia włoskiego: poco 'mało' i curanté 'zważać, 'martwić się. Imię senatora wskazuje zatem na osobę, która się niczym nie przejmuje, która niczego nie szanuje i na nic nie zważa. Przybylski przeniósł tę nazwę i wprowadził do tekstu jej dwa spolszczone warianty. Znaczenie tego imienia, zarówno w oryginale, jak i w tłumaczeniu Przybylskiego, jest widoczne tylko dla tych, którzy znają język włoski (Chrobak, 2009, s. 54). Drugi tłumacz zastąpił imię senatora inną nazwą, której pochodzenie nie jest znane. Funkcja semantyczna antroponimu Pococuranté nie została zatem zachowana w tłumaczeniu Boya.

W dalszej części analizy zajmiemy się tymi nazwami, które nie są neologizmami, ale nazwami już istniejącymi w świecie rzeczywistym. Na podstawie kilku przykładów zobaczymy, że tłumacze w większości przypadków wybierają tę samą technikę tłumaczeniową, to znaczy wprowadzają do przekładów polskie odpowiedniki nazw własnych, oczywiście pod warunkiem, że takowe istnieją: 
(8)

V: Martin

P, B: Marcin

(9)

$\mathrm{V}$ : Jacques

P: Jakub

B: Jakób.

W przykładzie (9) widzimy różnicę w pisowni nazwy własnej w polskich tłumaczeniach, która wynika z odmiennych zasad ortografii w XVIII i XX wieku. Dalsze przykłady traktowania nazw własnych pozwolą nam zaobserwować jeszcze więcej przypadków różnic w pisowni wynikających z ewolucji języka polskiego.

Jeśli imię zawarte w oryginale nie posiada swojego odpowiednika w języku polskim, tłumacze stosują przeniesienie z niewielką zmianą w pisowni u Przybylskiego:

(10)

V: don Issachar

P: Dom-Issachar ${ }^{9}$

B: don Issachar

lub używają zupełnie różnych technik:

(11)

V: Paquette

P: Pakietka

B: Pakita.

W przykładzie (11) widzimy, jak zostało potraktowane w tłumaczeniach imię Paquette, które nosi służąca. Nazwa ta pełni w tekście przede wszystkim funkcję semantyczną, która nie została zachowana przez polskich tłumaczy. Paquette pochodzi prawdopodobnie od nazwy pospolitej pâquerette ('stokrotka') i odwołuje się do urody służącej. Przybylski przeniósł nazwę i spolszczył ją pod postacią zdrobnienia, tak jak ma to miejsce w oryginale (sufiks -ette), natomiast Boy wprowadził do tekstu podobnie brzmiące imię, ale pochodzące z języka hiszpańskiego: $\mathrm{Pa}$ quita. Forma została dostosowana do języka polskiego. Można przypuszczać, że użycie w tłumaczeniu hiszpańskiego imienia wynika z wpływu literatury hiszpańskiej, która w XVIII wieku nie była jeszcze tak rozpropagowana i tak licznie tłumaczona, jak w latach późniejszych. Obie wersje imienia Paquette w polskich tłumaczeniach nie mają wiele wspólnego ze stokrotką i kojarzą się raczej z takimi słowami jak pakiet czy paka.

\footnotetext{
9 Nie udało nam się określić, dlaczego w tym tłumaczeniu widnieje francuska forma tytułu don, która nadawana jest jedynie zakonnikom, w szczególności benedyktynom (na przykład sławny Dom Pérignon). Być może chodzi tu o zwykły błąd w druku.
} 
Na podstawie przykładów z grupy pierwszej możemy już stwierdzić, że Przybylski miał wyraźną skłonność do spolszczania obcych imion, natomiast Boy-Żeleński częściej przenosi je do tłumaczenia w niezmienionej formie. Rzucają się również w oczy różnice w pisowni niektórych nazw, które wynikają z ewolucji języka, zwłaszcza zmian zasad ortografii polskiej. Funkcje: ekspresywna, socjologiczna i charakteryzująca antroponimów są zachowane przez tłumaczy, natomiast jeśli chodzi o funkcję semantyczną, to w niektórych przypadkach może ona być niewidoczna dla polskiego czytelnika.

\section{Nazwy bohaterów powiastki, postaci autentyczne}

W tej grupie znajdują się nazwy własne, które zostały potraktowane w podobny sposób przez obu tłumaczy: w tłumaczeniach znalazły się ich ekwiwalenty z języka polskiego:

(12)

V: Achmet III

P: Achmet III (+ przypis: (i) Złożony z tronu roku 1730.)

B: Achmet III

(13)

V: Charles-Édouard

P: Karol Edward (+ przypis: (l) Pretendent, który podczas wojny r. 1747 Francji z Anglią kusił się odzyskać tron angielski, lecz daremnie przyjacioł jego, prawdziwie taki był los po przegranej.)

B: Karol-Edward.

Rzuca się jednak w oczy obecność przypisów u Przybylskiego, w których zawarte są podstawowe informacje związane $\mathrm{z}$ każdym bohaterem. Wprowadzenie przypisów do tekstu tłumaczenia jest często związane $\mathrm{z}$ chęcią pomocy czytelnikowi w lepszym zrozumieniu lektury. Tak również było w czasach oświecenia, zwłaszcza w przypadku tekstów trudnych i szczególnie znaczących w dziejach kultury, które często opatrywano objaśnieniami. Ponadto obecność przypisów w tłumaczeniu Przybylskiego jest również przykładem funkcjonującej w drukach dawnych tradycji opatrywania utworów objaśnieniami, komentarzami czy uwagami, co czyniło książkę pozycją szczególnie wartościową, dopracowaną przez autora lub wydawcę, skierowaną do szerokiego odbiorcy.

\section{Nazwy postaci autentycznych związanych z Voltaire'em (przywoływane przez bohaterów)}

W tej grupie znajduje się siedem nazw postaci, które są związane w pewien sposób z życiem Voltaire’a. Chodzi tutaj głównie o jego wrogów, krytyków literackich, ale także o słynną aktorkę, odtwórczynię ról bohaterek sztuk pisarza, czyli mademoiselle Clairon:

V: mademoiselle Clairon 
P: panna Kleron

B: panna Clairon

V: Gauchat

P: $[\ldots]$

B: Gauchat

V: Robeck

P: -

B: Robeck.

W przykładzie (14) po raz kolejny ujawnia się skłonność autora pierwszego przekładu Kandyda do spolszczania obcych nazw. Drugi tłumacz - jak to mogliśmy zaobserwować wcześniej znów przenosi nazwę do tłumaczenia w niezmienionej postaci.

Po przeanalizowaniu wszystkich powyższych przykładów rzuca się w oczy fakt, że Przybylski opuścił dużą część nazw z tekstu. Co więcej, nazwy te są pominięte wraz z całym fragmentem (w którym bohaterowie rozprawiają o literaturze) stanowiącym krytykę Voltaire’a wymierzoną w ludzi ze swojego otoczenia (np. właśnie owych krytyków literackich publikujących negatywne opinie o jego dziełach). Opuszczenie tych nazw przez Przybylskiego może wynikać z funkcji mimetycznej, jaką pełnią one w tekście. Voltaire wprowadza postaci pochodzące z jego najbliższego otoczenia, których polski czytelnik nie byłby prawdopodobnie w stanie zidentyfikować bez pomocy tłumacza lub sięgnięcia do źródeł. Przybylski zadecydował więc o usunięciu nazw tych postaci, jak i całego fragmentu powiastki ze swego tłumaczenia. Te opuszczenia nie mają oczywiście żadnego wpływu na główne przesłanie dzieła, ale pozbawia czytelnika pewnych informacji związanych z epoką autora.

\section{Nazwy postaci historycznych (przywoływane przez bohaterów)}

Nazwy postaci historycznych są przez tłumaczy traktowane na dwa sposoby - albo zostaje wprowadzony polski ekwiwalent danej nazwy, albo stosowane jest przeniesienie bez zmian w pisowni. Ponadto w przykładach (17) i (18) ponownie możemy zauważyć różnice w pisowni:

V: Sédécias

P: Sedecyjasz

B: Sedecjasz

V: Darius

P: Daryjusz

B: Darjusz 
(19)

V: Raleigh

P: Raleigh

B: Raleigh.

Kolejny przykład jest niezwykle interesujący, gdyż pierwszy tłumacz zastąpił nazwę własną inną nazwą, której towarzyszy przymiotnik w stopniu najwyższym:

V: Mahmoud

P: najpotężniejszy Achmet

B: Mahmud.

Imię Mahmoud odwołuje się do bratanka sułtana Achmeta III wyniesionego na tron Imperium Osmańskiego w 1730 roku. Możliwe, iż Przybylski nie chciał wprowadzać do tekstu zbyt wielu nieznanych polskiemu czytelnikowi nazw i skoncentrował się jedynie na ukazaniu znaczenia postaci poprzez dodanie przymiotnika w stopniu najwyższym. Rezultatem zastosowanej przez tłumacza techniki jest zniknięcie funkcji dydaktycznej, którą pełni ta nazwa w tekście.

\section{Nazwy postaci literackich i postaci związanych z religią (przywoływane przez bohaterów)}

W ostatniej grupie zostały zgromadzone nazwy postaci literackich oraz nazwy postaci związanych z trzema wielkimi religiami: chrześcijaństwem, islamem i judaizmem. W prawie wszystkich przypadkach tłumacze zastępują nazwy ich polskimi ekwiwalentami (zwłaszcza jeśli chodzi o religię chrześcijańską, obecną prawie w całej Europie). W niektórych przykładach po raz kolejny widoczne są różnice w pisowni:

V: Moïse

P, B: Mojżesz
$\mathrm{V}$ : Ascanius
P: Askanijusz
B: Askaniusz

V: Lavinia

P: Lawinija

B: Lawinia.

Szczególnym przypadkiem w tej grupie nazw jest antroponim Mahomet, który został zastąpiony przez Przybylskiego nazwą Alkoran. Być może w XVIII wieku słowem silniej kojarzącym 
się z islamem była nazwa świętej księgi niż imię proroka. Kolejny raz funkcja informacyjna nazwy własnej została wymazana przez pierwszego tłumacza:

V: Mahomet

P: Alkoran

B: Mahomet.

Analiza traktowania antroponimów w polskich przekładach powiastki Voltaire’a Candide pozwoliła zaobserwować pewne tendencje tłumaczeniowe w obu tekstach. W pierwszym przekładzie pochodzącym z XVIII wieku widoczne są pominięcia niektórych nazw własnych oraz przypisy mające na celu ułatwienie lektury czytelnikowi. Formy obcych nazw są częściej spolszczane niż przenoszone bez zmian w pisowni. W przekładzie Boya-Żeleńskiego dominuje natomiast strategia egzotyzacji - tłumacz częściej przenosi nazwy własne w niezmienionej postaci, nie stosuje pominięć, rzadko zastępuje daną nazwę inną nazwą i nie wprowadza przypisów. Po zestawieniu przykładów z obu tłumaczeń ujawniły się również różnice w pisowni, które wynikają z odmiennych zasad ortografii w obu epokach.

Elementy składające się na horyzont translatorski tłumacza odgrywają dużą rolę w traktowaniu antroponimów w przekładach powiastki. Widoczne jest to na przykład właśnie w różnicach w pisowni lub odmiennych formach słów, co wynika z ewolucji zasad ortografii języka polskiego. Pominięcie niektórych nazw własnych przez Przybylskiego czy też wprowadzenie przypisów objaśniających niektóre z nich może wynikać z przeświadczenia pierwszego na gruncie polskim tłumacza tego utworu Voltaire’a o trudnościach w szerokim czytelniczym odbiorze tekstu zawierającego liczne ważkie refleksje filozoficzne oraz aktualne, historyczne i polemiczne odwołania, a na dodatek stanowiącego nowość na polskim rynku wydawniczym. Wiązała się z tym troska, a i ambicja Przybylskiego o stosowne wyposażenie edycji przekładu, jak to wówczas czyniono również w odniesieniu do autorów i tekstów doskonale znanych polskim czytelnikom. W tłumaczeniu z XX wieku zostały zachowane wszystkie antroponimy, co można wyjaśnić dobrze już wówczas ugruntowaną w Polsce wiedzą o twórczości Voltaire’a i jej filozoficznych kontekstach, a także zapewne również postępem technologicznym (druk oraz szerszy obieg książki i prasy), dzięki czemu współcześni Boya byli lepiej przygotowani do odbioru tekstu tej najwyżej cenionej powiastki sławnego francuskiego pisarza.

Możemy też zauważyć, że funkcja, jaką pełni dana nazwa własna w tekście przekładanego utworu, jest również niezwykle istotna i może mieć wpływ na decyzję tłumacza, co szczególnie rzuca się w oczy w traktowaniu antroponimów pełniących funkcję ekspresywną w oryginale zarówno Przybylski, jak i Boy użyli tej samej techniki, czyli przeniesienia. Forma nazw była na tyle ważna, że tłumacze wręcz „musieli” zachować ją w tłumaczeniach.

Zmiana horyzontu translatorskiego, która nastąpiła na przestrzeni stu pięćdziesięciu lat, miała więc kluczowy wpływ na powstanie serii przekładowej powiastki Voltaire’a. Wpływ horyzontu na traktowanie antroponimów w utworze jest znaczący, ale nie we wszystkich przypadkach odgrywa tak samo ważną rolę. Często tłumacze postępują zgodnie z tym, co narzuca im tekst - w tym przypadku są to funkcje nazw własnych. Poza tym wprowadzenie przypisów do tekstu 
nie zawsze musi być wpisane w horyzont translatorski ani wynikać na przykład ze specyfiki danego gatunku literackiego, ale może być rezultatem subiektywności tłumacza, który sam decyduje o tym, czy chce poinformować o czymś czytelnika i pomóc mu w lekturze, czy woli pozostawić go samemu sobie ${ }^{10}$.

\section{Bibliografia podmiotowa}

Voltaire (1780). Kandyd Wszędobylski czyli najlepszość. Przeł. J.I. Przybylski. Lipsk [i.e. Warszawa]: Dufour, Piotr. Pobrane z: http://www.dbc.wroc.pl/dlibra/docmetadata?id=25648\&from=publication (dostęp: 1.12.2016)

Voltaire (1781a). Dobry Bramin, czyli niechcący być uszczęśliwionym fanatykiem. Powieść filozoficzna. Lublin. Voltaire (1781b). Mądry Memnon. Powieść z francuskiego. Lublin.

Voltaire (1889). Candide. W: Voltaire, Zadig; Candide; Micromégas. Paris: C. Marpon et E. Flammarion. Pobrane z: ark:/12148/bpt6k6209549f (1.12.2016).

Voltaire (1911). Refleksje. Zebrał, przeł., przedmową opatrzył Glass. Lwów.

Voltaire (1931). Kandyd. Przeł. T. Boy-Żeleński. Warszawa: Biblioteka Boy’a.

Zabuesnig von, J. Ch. (1781). Historyczno-krytyczne wiadomości o życiu i pismach pana Woltera i inszych nowych filozofów. Wykład z niemieckiego przez J. P. jednego z akademików krakowskich. Warszawa: Drukarni J[ego]. K[rólewskiej]. M[oś]ci i Rz[ecz]p[ospo]l[i]tey u XX. Scholarum Piarum.

Zabuesnig von, J. Ch. (1784) Historyczno-krytyczne wiadomości o życiu i pismach trzydziestu i trzech filozofów naszego wieku, opisane i tłumaczone z niemieckiego. Kraków: Drukarnia Ignacego Gröbla.

\section{Bibliografia przedmiotowa}

Ballard, M. (2001). Le nom propre en traduction. Paris: Ophrys.

Berman, A. (1995). Pour une critique des traductions: John Donne. Paris: Gallimard.

Błoński, J. (1958). Szekspir przekładu. W: T. Żeleński (Boy), Pisma. Red. H. Markiewicz. T. 14. Antologia literatury francuskiej (s. 5-11). Warszawa: PIW.

Bochnakowa, A. i in. (2012). Wyrazy francuskiego pochodzenia we wspótczesnym języku polskim. Kraków: Wydawnictwo Uniwersytetu Jagiellońskiego.

Brudnicka, J. (1964). Informacja o wierszach Stanisława Kostki Potockiego. Pamiętnik Literacki, 55 (2), 481-499.

Chrobak, M. (2009). Optymizm Kandyda oraz inne problemy oświeconych tłumaczy, Kraków: Wydawnictwo Uniwersytetu Jagiellońskiego.

Gary-Prieur, M.-N. (1991). Le nom propre constitue-t-il une catégorie linguistique? Langue française, 92 (1), $4-25$.

10 Rezultaty badań Elżbiety Skibińskiej przedstawione w artykule Przypisy tłumacza w osiemnastowiecznych polskich przekładach pokazują, że liczba przypisów w polskich przekładach z XVIII wieku nie zawsze musi być związana z gatunkiem, do którego należy tłumaczony tekst (Skibińska, 2009, s. 20-48). 
Hen, J. (2008). Boy-Żeleński błazen - wielki mąż. Warszawa: Wydawnictwo W.A.B.

Jean, C. (1976). Wstęp. W: C. Jean (red.). Boy-Żeleński 1874-1974. Warszawa: Uniwersytet Warszawski.

Karłowicz, J., Kryński, A., Niedźwiedzki, W. (1927). Słownik języka polskiego. T. 8: Z-Ż. Warszawa: Wydawnictwo Kasy im. Mianowskiego.

Kosyl, Cz. (1992). Nazwy własne w prozie Jarosława Iwaszkiewicza. Lublin: Wydawnictwo Uniwersytetu Marii Curie-Skłodowskiej.

Kozioł, P. (2010). Tadeusz Boy-Żeleński, Pobrane z: http://culture.pl/pl/tworca/tadeusz-boy-zelenski (18.09.2016).

Leroy, S. (2004). Le Nom propre en français. Paris: Ophrys.

Sinko, Z. (1982). Powiastka w oświeceniu stanisławowskim. Wrocław: Zakład Narodowy im. Ossolińskich Wydawnictwo PAN.

Skibińska, E. (2011). «C’est la faute à... Boy»: Les traductions «canoniques» sont-elles un obstacle à la retraduction? W: E. Monti, P. Schnyder (red.) Autour de la retraduction. Perspectives littéraires européennes (s. 405-418). Paris: Orizons.

Skibińska, E. (2009). Przypisy tłumacza w osiemnastowiecznych polskich przekładach. W: E. Skibińska (red.). Przypisy tłumacza (s. 20-48). Wrocław-Kraków: Księgarnia Akademicka.

Snopek, J. (1994). Jacek Idzi Przybylski (1756-1819). W: T. Kostkiewiczowa, Z. Goliński (red.), Pisarze polskiego oświecenia. T. 2 (s. 207-229). Warszawa: Wydawnictwo Naukowe PWN.

Stróżyński, T. (1994). Pracowite błazeństwo. O przekładach Tadeusza Żeleńskiego-(Boya). W: M. Abramowicz, D. Bertrand, T. Stróżyński (red.). Humor europejski (s. 405-424). Lublin: Wydawnictwo Uniwersytetu Marii Curie-Skłodowskiej.

Strycharska-Brzezina, Maria (2012 ). Ku utopii graficznej? Projekty modernizacji alfabetu polskiego od Oświecenia do międzywojnia. Kraków: Collegium Columbinum.

Wójcicki, J. (2006). Przybylski, czyli Voltaire. W: Kandyd Wszędobylski, czyli Najlepszość oraz inne przekłady Jacka Idziego Przybylskiego. Oprac. Jacek Wójcicki. Kraków-Warszawa: Collegium Columbinum.

Ziętarska, J. (1969). Sztuka przekładu w pogląach literackich polskiego Oświecenia, Wrocław: Zakład Narodowy im. Ossolińskich Wydawnictwo PAN.

Żeleński (Boy), T. (1958). Wstęp. W: T. Żeleński (Boy), Pisma. Red. H. Markiewicz. T. 14. Antologia literatury francuskiej (s. 15-44). Warszawa: PIW.

\section{Proper nouns (anthroponyms) in Polish translations of Voltaire's philosophical novel "Candide ou l'optimisme"}

Summary

The aim of this paper is to verify how the translational horizon influences the treatment of anthroponyms in two Polish translations of Voltaire's philosophical novel "Candide ou l'optimisme". The paper includes the comparative analysis of selected names of human beings coming from the translations chosen and from the original. A long period between the appearance of translations (about one hundred and fifty years) and the related changes had a major impact 
on the treatment of anthroponyms. The paper shows that the translational horizon plays a crucial role in the translation process and is demonstrated by various translation techniques used in the text. However, the differences in the treatment of anthroponyms are not always linked to the changes of translational horizon but are often the result of the translator's subjectivity. The translation process depends also on the functions assigned to the anthroponyms in the original.

Słowa kluczowe: Wolter, Jacek Przybylski, Tadeusz Boy-Żeleński, Kandyd, horyzont translatorski, subiektywność tłumacza

Keywords: Voltaire, Candide, Jacek Przybylski, Tadeusz Boy-Żeleński, Candide, translational horizon, retranslation, translator's subjectivity 